\title{
A STUDY OF TENANTS' MAINTENANCE AWARENESS, RESPONSIBILITY AND SATISFACTION IN INSTITUTIONAL HOUSING IN NIGERIA
}

\author{
Adebayo A. OLADAPO \\ Department of Quantity Surveying, Faculty of Environmental Design \\ and Management, Obafemi Awolowo University, Ile-Ife, Nigeria \\ E-mail: adeladapo@yahoo.com
}

Received 12 September 2005; accepted 22 May 2006

\begin{abstract}
The housing problem in Nigeria is both quantitative and qualitative. The qualitative aspect, which has to do with the maintenance of the existing stock, has assumed greater significance because of the need to preserve the existing stock and bring it to acceptable standards of living. Tenants in institutional housing are major stakeholders who directly bear the brunt of the disrepair of the houses. Hence they have a role to play to optimise the maintenance of their houses within the very limited resources available to the maintenance departments. The study was carried out to evaluate the maintenance awareness and responsibilities of tenants and quantitatively analyse their satisfaction with the state of maintenance of their houses. The results showed that the tenants had a high level of maintenance awareness and responsibility but their satisfaction with the maintenance of their houses was just average.
\end{abstract}

KEYWORDS: Maintenance; Institutional housing; Tenant issues; Nigeria

\section{INTRODUCTION}

Housing is universally acknowledged as the second most essential human need after food and is a major economic asset in every nation. This fact is underscored by a statement in the foreword to Foster's (2000) report that "Good quality housing provides the foundations for stable communities and social inclusion". So and Leung (2004) have also established a positive correlation between the quality of life and the comfort, convenience and visual appeal of houses.

A United Nations report in 1976 described the problem of housing in Africa as far from being only technical and economic, but also a problem of social development in its widest sense, encompassing legal, educational and community-building aspects and directed at real human and social improvement (van Wyk and van Wyk, 2001). Indeed, van Wyk and van Wyk (2001) made the important point that "it is apparent that the problems of housing, urban development and economic development are closely interrelated". They added that housing certainly has a large potential to contribute towards providing people with 'the opportunity to live full human lives', and hence contributes positively towards all aspects of development - psychological, social, economic, cultural and institutional, in the individual, community and societal contexts. 
Against this background, it is not surprising that since the colonial era (before independence in 1960) successive governments in Nigeria have embarked on programmes to provide housing for public servants. These programmes recorded very little success, with some achieving as little as $15 \%$ of their set targets. Nigeria therefore accumulated a housing deficit estimated at five million new units by the year 2000, the target year of the UN's "Shelter for All" agenda. In addition, there was a backlog of maintenance required to bring existing units to acceptable standards of living, equivalent to the cost of three million new units (Federal Republic of Nigeria, 1991).

It is clear from the foregoing that the housing problem in Nigeria is both quantitative and qualitative. In fact, Ozdemir (2002) regards the quality problem as the main problem in housing and advocates that housing policies should focus not only on the production of new housing units but also on improving the standards of the existing stock to meet current and changing standards. The qualitative aspect of the housing problem is the problem of maintenance. The problem of maintenance arises because buildings inevitably deteriorate with time due to effect of various causes.

As stated earlier, research has established a positive correlation between the quality of life of tenants and the comfort, convenience and visual appeal of houses. These attributes of a house, no doubt, are a function of its state of maintenance. This is because the essence of maintenance, by definition, is to keep a building in a condition appropriate to its use (ElHaram and Horner, 2002). The implication of this reality is that tenants have a very high stake in the maintenance of their houses, whether they are responsible for the maintenance or not. In fact, Bitner et al. (1997) believe that in the provision of services (like housing maintenance and repairs), the customers (including tenants) have vital roles to play in creating service outcomes to ultimately determine the value and level of satisfaction they receive. It is for this reason that this study aimed at assessing tenants' maintenance awareness and responsibility as well as their level of satisfaction with the maintenance of their houses.

To achieve the stated aim of this study, the following research questions were raised:

- What is tenants' level of understanding of the concept of maintenance?

- In what ways do tenants contribute to the state of maintenance of their houses?

- How do tenants prioritise competing maintenance demands?

- What is the tenants' level of satisfaction with the state of maintenance of their houses?

The following hypotheses were formulated and tested to seek answers to some of the research questions:

1. Null hypothesis $\left(\mathrm{H}_{0}\right)$ : There is no agreement among tenants in their maintenance priority preferences.

Alternative hypothesis $\left(\mathrm{H}_{1}\right)$ : There is agreement among tenants in their maintenance priority preferences.

2. Null hypothesis $\left(\mathrm{H}_{0}\right)$ : There is no significant difference between the maintenance priority preferences of tenants and the maintenance departments.

Alternative hypothesis $\left(\mathrm{H}_{1}\right)$ : There is significant difference in the maintenance priority preferences of tenants and the maintenance departments.

3. Null hypothesis $\left(\mathrm{H}_{0}\right)$ : There is no agreement among tenants in their satisfaction rating of the level of maintenance of their houses.

Alternative hypothesis $\left(\mathrm{H}_{1}\right)$ : There is agreement among tenants in their satisfaction rating of the level of maintenance of their houses.

4. Null hypothesis $\left(\mathrm{H}_{0}\right)$ : There is no significant correlation between users' perception of the level of maintenance of a particular building and the prevalent level of user satisfaction.

Alternative hypothesis $\left(\mathrm{H}_{1}\right)$ : There is significant correlation between users' perception of the level of maintenance of a particular 
building and the prevalent level of user satisfaction.

\section{INSTITUTIONAL HOUSING IN NIGERIA}

As a deliberate strategy, Nigeria's housing policies have over the years encouraged employers of labour in both the public and private sectors to provide housing for their workers. Thus in addition to barracks accommodation for the armed forces, the police and other paramilitary organisations, institutions like the Nigerian Railways, educational institutions (especially the universities) and even multinational oil companies, etc. have developed large housing estates for their employees.

Most of Nigeria's universities operate the residential system by which housing accommodation is provided for both students and staff on campus. Over the years these institutions have developed large housing estates, which are among the largest estates in the country in terms of land areas and number of units. Unlike most others (in both the public and private sectors), the university housing estates have well-organised technical departments responsible for the maintenance of the houses. For this reason and the fact that the university housing maintenance organisations are more accessible to researchers than most others, three large university housing estates having a total of 1357 units were selected for this study.

\section{TENANTS' ROLES AND SATISFACTION IN HOUSING MAINTENANCE}

Building users generate maintenance in two major ways. First, their normal use of buildings results in natural wear and tear as envisaged in the building design and specification. Second, their abuse of buildings, especially through vandalism, results in wilful damage to a building. Another way is perhaps what Olubodun (1996) called passive vandalism, which is wilful neglect of affordable mainte- nance responsibility by a user. This no doubt leads to further deterioration of the building condition and generates more maintenance. In their study of local authority housing in Scotland, El-Haram and Horner (2002) identified tenant factors like high expectation of tenants, improper use of the property and delay in reporting failures as very significant contributors to housing maintenance costs.

The primary initiators of maintenance action are the building owner and/or tenants, although such other interested parties as building inspectors, insurance companies, employees and their trade unions and concerned members of the public directly or indirectly exert some influence on the amount of maintenance work undertaken. A building owner normally seeks to preserve the condition of his property by the insertion of appropriate clauses in the lease/tenancy agreement to demarcate owner/ user responsibilities for maintenance. In some countries such demarcations are laid down by statute. For example, in the UK, section 11 of the Landlord and Tenant Act of 1985 provides that in any lease for less than seven years, the landlord shall be responsible for repairing the structure and exterior of the building as well as the mechanical and electrical installations (Lee, 1995).

Whatever the owner/user demarcation of maintenance responsibility, the user has a primary responsibility to notify defects to the appropriate quarters for remedial action. Seeley (1987) identified six commonly used means of notification by users as follows:

- Telephone call from tenant;

- Return of pre-paid complaint card by tenant;

- Letter from tenant;

- Officer of housing authority finding defects;

- Tenant notifying defect in person at a depot or housing office;

- Tenant notifying complaint to officer of housing authority on site.

Kangwa and Olubodun (2003b) are of the view that owner-occupiers must have an un- 
derstanding or knowledge of the severity of the defects observed or anticipated in their dwelling structures. This view, no doubt, should also apply to tenants. Unfortunately, however, lack of awareness among homeowners and tenants remains a barrier to prompt notification of defects as most home owners/tenants face difficulties in recognising the symptoms of even the most basic forms of building decay (Kangwa and Olubodun, 2003a). The reporting delay time is the time which elapses between the detection/observance of a defect and report to the maintenance department by the user. This depends mainly on the inconvenience which the defects cause the user and is not a measure of the seriousness of the defect (Lee, 1995). Lack of maintenance awareness prevents tenants from identifying in time the relative value and urgency of a repair (Richardson, 1991) and also manifests in the wrong notion that housing deterioration has no impact on tenants' standard of living (Kangwa and Olubodun, 2003a).

Users also have a role in evaluating the effectiveness of maintenance management systems to provide feedback to maintenance managers. This is usually done in post-occupancy evaluations which measure user satisfaction as an indicator of a building's utility. This system very often excludes building users from the early design decision-making process. McGeorge and Betts (1990) have expressed the view that, in addition to post-occupancy evaluation, a pre-occupancy stakeholder analysis could enhance the utility of a building to the user particularly in the area of maintenance planning. There is no doubt that the end user must inevitably bear some of the consequences of errors in planning. The cost of such errors to the user could be in terms of higher maintenance costs or health hazards.

Two categories of stakeholders, namely owners and users are identified in the normal convention for stakeholder analysis. In the context of housing there could be some overlap between these two categories. Hence McGeorge and Betts (1990) have cautioned that making a distinction between them could be counterproductive. There is no doubt, however, that stakeholders in housing are likely to have conflicting objectives, which a pre-occupancy evaluation can help to balance.

\section{Tenant Satisfaction in Housing}

Housing satisfaction refers to the degree of contentment experienced by an individual or family with regard to the current housing situation (McCray and Day, cited in Djebarni and Al-Abed, 2000). It is an index of the level of contentment with current housing conditions, and refers to an entire continuum of satisfaction from "very dissatisfied" to "very satisfied" rather than just a state of being "satisfied" (Morris, cited in Djebarni and Al-Abed, 2000).

Housing is more than shelter and the habitability of a house depends not only on the physical characteristics of the dwelling but also on the social, cultural and behavioural characteristics of the users. This is why Lu (1999) has expressed the view that housing satisfaction is not only an important component of individuals' quality of life but also determines the way they respond to the residential environment. A dwelling that is adequate from the physical or design point of view may not necessarily be adequate or satisfactory from the users' point of view (Onibokun, cited in Oladapo, 2005). On this basis, according to Oladapo (2005), he advocated a systems approach to the concept of user satisfaction involving four interacting subsystems-the tenant subsystem, the dwelling subsystem, the environment subsystem and the management subsystem (Figure 1).

The model in Figure 1 depicts a system of tenant-dwelling unit-environment-management interaction which produces a housing situation which the tenant component judges as adequate and satisfactory according to his housing needs and expectations. Djebarni and Al-Abed (2000) have combined the adequacy and satisfaction requirements into a housing effectiveness model. 


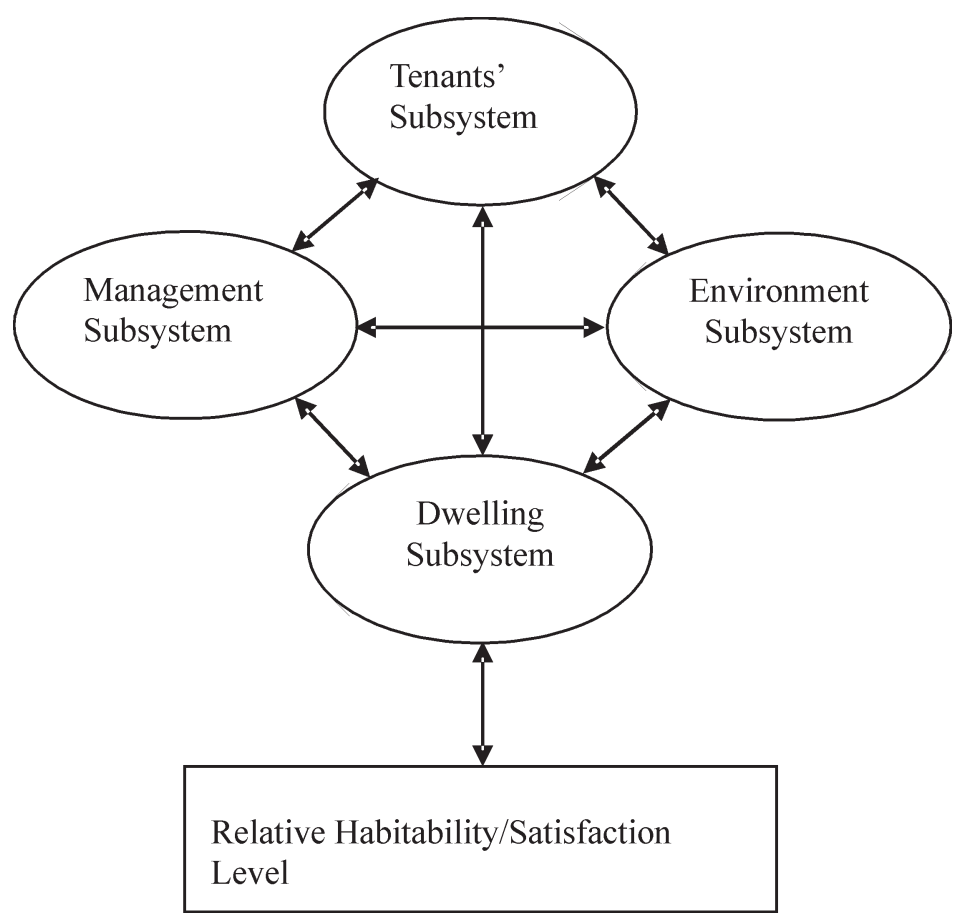

Figure 1. Onibokun's systems approach to user satisfaction Source: Oladapo (2005)

At the heart of the user satisfaction model in Figure 1 is the tenant (the fourth subsystem) who is the recipient of all the feedback from the other subsystems and is therefore the central focus of the model on which satisfaction in housing management should be based. In this model, the housing unit is a part of an environment and must of necessity interact with the environment subsystem which has influence, negative or positive, on the inhabitants' living conditions and their satisfaction with a particular housing unit within an environment. There is also the management subsystem which comprises the whole institutional framework under which public housing is administered.

As stated earlier, housing is more than shelter. Hence, according to Ukoha and Beamish (1997), "simply providing housing units does not measure the success of housing programs in either developed or developing countries. The suitability of the living environment to the needs of the residents is essential for housing programmes to be judged successful". In their research on public housing in Abuja, Nigeria, Ukoha and Beamish found that the management dimension (including maintenance) was the primary source of dissatisfaction among tenants. Measuring housing satisfaction is important because, according to $\mathrm{Lu}$ (1999), an understanding of the factors that make a tenant satisfied or dissatisfied can play a critical role in formulating successful housing policies.

From the literature, the indicators of tenant satisfaction with housing maintenance are summarised as:

- Procedure for requesting repairs (Koebel and Etuk, 1998);

- The courtesy of the maintenance staff (Koebel and Etuk, 1998);

- Speed of response and execution by maintenance staff (Koebel and Etuk, 1998; Rosenbaum et al., 1998; National Housing Federation, 2001); 
- Level of mess and nuisance caused by maintenance staff (National Housing Federation, 2001);

- The quality of work done by maintenance staff (National Housing Federation, 2001);

- Overall maintenance of the houses (National Housing Federation, 2001).

Examining a maintenance management system using these indicators permits a comprehensive survey of the satisfaction of tenants with the system. However, in the light of the criticisms of tenant satisfaction surveys in housing by several authors, including Satsangi and Kearns (1992) and Koebel and Etuk (1998), a fundamental problem arises as to whether tenant satisfaction surveys can be used to judge maintenance management performance. Indeed, Satsangi and Kearns (1992) argued that conventional tenant satisfaction surveys which set out to measure tenants' satisfaction with service provided often end up measuring factors independent of the provider's performance. They further argued that "the use of the satisfaction score as an indicator of the effectiveness of the service provider, without taking into account the likely impact of other factors upon the rating, is highly misleading". To overcome some of these limitations, they advocated more reliable measures of tenants' satisfaction which should take into account that (a) not all consumers are likely to have perfect information; (b) degrees of satisfaction vary for different individuals in different circumstances; (c) most housing services have no absolute criteria of judgment; (d) judgment of service quality (and degree of satisfaction) are subjective, and dependent upon culture, social identity, etc.

In spite of these criticisms, however, the fact still remains that no better alternative has been found to tenant satisfaction surveys. Even its most ardent critics recognise some of its merits and can only suggest modifications as demonstrated by Satsangi and Kearns (1992). In fact, Ngo (1990) has stated that the degree of user satisfaction is one of the indicators of the level to which a building has been main- tained. Several other researchers, including Amole (1989), Walters (1999) and Foster (2000) have supported this view. This makes tenants' satisfaction a good measure of housing maintenance performance.

\section{RESEARCH METHODOLOGY}

A questionnaire survey of three university housing estates was carried out between February and June 2004. The estates, which are among the largest in institutional housing in Nigeria, had a combined total of 1357 units. Of the 1310 units occupied at the time of the survey, every other house in an estate was chosen. This represented a simple random sample size of $5 \%$. The questions were framed to test the tenants' appreciation of the need for maintenance, and elicit responses on their responsibilities and priority preferences, as well as their satisfaction with the maintenance state of their houses. Borrowing from the suggestions of Varady and Carrozza (2000) for a proper measure of tenant satisfaction, the questionnaire covered different components of satisfaction with housing maintenance and elicited both quantitative and qualitative information from the respondents.

The questionnaires were personally administered by trained research assistants to the head of each selected household. Most of the questions used Likert type scales to elicit respondents' perceptions. To minimise the problem of leniency, central tendency and the "halo effect" associated with such scales, the survey instrument adopted a seven-point scale (after Walker, 1994). Thus the responses ranged from strongly disagree $=1$ to strongly agree $=7$. The significant agreement or otherwise with the notion being tested was determined by adopting the mid-point value of the index (that is $4=$ unsure) as the hypothesized mean (Coakes and Steed, 2001). This implies that any result significantly different from this uncommitted or unsure value was assumed to be either positive or negative to the notion being tested (Pullin and Haidar, 2003). To test the 
reliability of the questionnaires used in this study, the Cronbach's $\sigma$ values were calculated (using the SPSS package) for the 7 point scale and found to be very high between 0.80 and 0.89 .

The data were analysed with the SPSS software using the percentile method, Kendall's coefficient of concordance, the Mann-Whitney test and severity index analysis. The formula for the severity index is given as follows by Elhag and Boussabaine (1999):

$$
\text { S.I. }=\left\{\sum_{i=1}^{i=n} w_{i} f_{i}\right\} \times 100 \%
$$

where: S.I. is the severity index; $f_{i}$ is the frequency of response; $w_{i}$ is the weight for each rating (i.e. rating in scale/number of points in a scale), and $n$ is the total number of responses. The value $\left(f_{i} \times 100\right) / \mathrm{n}$ is the valid percentage as computed by SPSS.

\section{ANALYSIS AND DISCUSSION OF RESULTS}

Of the 655 questionnaires distributed, 406 were returned. This represents a response rate of $61.98 \%$, which is very good, according to Ellhag and Boussabaine (1999) and Idrus and Newman (2002) who have expressed the view that a response rate of $30 \%$ is good enough in construction. In addition, the 406 responses obtained gave the sample a confidence interval better than \pm 5.0 (De Vaus, 1996). The tenants' mean length of stay in the houses was 8.44 years, which indicated that on the average the tenants had lived in the house long enough to provide detailed information on the maintenance history of their houses. The results are presented on tenants' maintenance awareness, responsibility, priority preferences, performance rating of and satisfaction with the state of maintenance of their houses.

\subsection{Tenants' Maintenance Awareness and Responsibility}

As major stakeholders in housing maintenance, tenants are expected to understand and appreciate the need for maintenance. In Table 1 , only 8 respondents $(2 \%)$ had no idea why maintenance was necessary, while most of them $(77.8 \%)$ believed that maintenance was necessary to keep the house safe for habitation. This high level of maintenance awareness may encourage tenants to respond promptly to the detection of defects in their houses. In fact, Table 2 shows that more than a quarter $(28.6 \%)$ report faults promptly while about half $(44.5 \%)$ even fix minor faults themselves.

The high level of maintenance awareness and responsibility demonstrated by the tenants is reflected in the fact that $50.7 \%$ of the respondents believed that it was their duty to use the houses with care while only a negligible number $1.7 \%$ felt it was none of their business to contribute. Some tenants were even prepared to do some maintenance work themselves $(44.6 \%)$ or provide materials when the maintenance department did not have them $(30.8 \%)$.

Table 1. Tenants' awareness of the rationale for maintenance

\begin{tabular}{lll}
\hline Reason & Frequency & Percent \\
\hline To keep the house safe for habitation & 316 & 77.8 \\
To preserve the house from decay & 242 & 59.6 \\
To keep the house beautiful and presentable & 257 & 63.3 \\
To retain the value of the house & 217 & 53.4 \\
Others & 19 & 4.7 \\
I don't know & 8 & 2.0 \\
\hline
\end{tabular}


Table 2. Tenants' response to the detection of defects in dwellings

\begin{tabular}{lll}
\hline Response & Frequency & Percent \\
\hline I report faults immediately no matter how small & 114 & 28.6 \\
I take my time to report minor faults & 3 & 7.5 \\
I fix minor faults myself & 177 & 44.5 \\
I only report life/health-threatening faults & 57 & 14.3 \\
I never report faults & 17 & 4.3 \\
Other & 3 & 0.08 \\
\hline
\end{tabular}

\subsection{Tenants' Priority Preferences}

All over the world, the dwindling resources available for maintenance (including Housing maintenance) in the face of ever-increasing maintenance demands requires that maintenance needs be prioritised to achieve the best value for money (Ramamurthy, 1990; Berger et al., 1991; Shen et al., 1998; Vijverberg, 2000). Traditionally, maintenance prioritisation has been done by maintenance departments without considering the views of tenants. Yip (2001) has argued in favour of tenant participation in this vital exercise to enhance tenants' satisfaction with maintenance systems. Towing this line, tenants were asked in this study to rank 16 common building defects in order of priority. In Table 3, the significance value of Kendall's coefficient of concordance is 0.000 (i.e. $<0.05$ ), indicating that there was agreement (at $5 \%$ significance level) among the tenants in their priority preferences. These results enable us to reject the null hypothesis that "There is no agreement among tenants in their maintenance priority preferences" and accept the alternative that "There is agreement among tenants in their maintenance priority preferences".

Tenants' priority preferences were then compared with those of the maintenance departments in Table 4 to see if there was any harmony between the two. It is not surprising that both the tenants and the maintenance staff ranked roof structure number 1 , as it is apparent to both groups that a collapsed roof exposes other parts of the building to the elements and can endanger both lives and property. On the other hand, both wall tile failure and floor tile failure, which pose no such dangers as for collapsed roof structures, were ranked number 16 (last) by the tenants and the maintenance departments respectively. These rankings by the tenants also show that they have a high level of awareness and understanding of the rationale for maintenance.

To determine whether the rankings of tenants and the maintenance departments differ significantly, the nonparametric method of the Mann-Whitney test is applied in Table 5. It is used to test the null hypothesis that two populations have identical distribution functions against the alternative hypothesis that the two distribution functions differ only with respect to location (median), if at all. The results in Table 5 indicate that only in three defects (defect in roof structure, floor tile failure and damaged taps/stop valves) out of the sixteen defects are there significant differences between the priority preferences of tenants and the maintenance departments $(\mathrm{p}<0.05$ at the $5 \%$ significance level). There-

Table 3. Kendall's coefficient of concordance test of agreement among tenants in priority ranking

\begin{tabular}{lllll}
\hline No of Cases & W & $\chi^{2}$ & df & Significance \\
\hline 341 & 0.318 & 1628.138 & 15 & 0.000 \\
\hline
\end{tabular}


Table 4. Comparison of priority preferences of tenants and technical staff

\begin{tabular}{|c|c|c|c|c|c|}
\hline \multirow[b]{2}{*}{ Defect } & \multirow[b]{2}{*}{ Variable label } & \multicolumn{2}{|l|}{ Tenants } & \multicolumn{2}{|c|}{ Maintenance departments } \\
\hline & & Mean score & Priority rank & $\begin{array}{l}\text { Mean } \\
\text { score }\end{array}$ & Priority rank \\
\hline Defects in roof structure & DEFRFSTRUCT & 3.38 & 1 & 1.43 & 1 \\
\hline Broken louvers/panes & BRKLV/PNS & 9.28 & 12 & 8.71 & 9 \\
\hline Wall cracks & WCRCKS & 8.66 & 9 & 8.10 & 7 \\
\hline Damaged internal door & DMGINDR & 9.73 & 13 & 9.38 & 11 \\
\hline Blocked drain & BLKDRN & 7.68 & 7 & 7.10 & 6 \\
\hline Floor tile failure & FLTLFLR & 12.45 & 14 & 14.00 & 16 \\
\hline Burst pipes/sanitary appliances & BSTPP/SANAPP & 5.77 & 3 & 6.76 & 5 \\
\hline Electrical faults & ELECTFLTS & 5.25 & 2 & 4.90 & 2 \\
\hline Damaged roofing sheets & DMGRFSHTS & 6.47 & 4 & 5.19 & 3 \\
\hline Wall tile failure & WLTLFLR & 12.81 & 16 & 12.52 & 14 \\
\hline Damaged external door & DMGEXDR & 6.80 & 5 & 5.90 & 4 \\
\hline Damaged painting/decoration & DMGPTG/DECOR & 12.77 & 15 & 13.86 & 15 \\
\hline Damaged ceiling & DMGCLG & 8.70 & 10 & 9.67 & 13 \\
\hline Damaged door locks & DMGDRLKS & 8.37 & 8 & 8.57 & 8 \\
\hline $\begin{array}{l}\text { Damaged door and window } \\
\text { frames }\end{array}$ & DMGDR/WNFRM & 9.25 & 11 & 9.29 & 10 \\
\hline Damaged taps/stop valves & DMGTPS/SVS & 7.59 & 6 & 9.43 & 12 \\
\hline
\end{tabular}

fore we accept the null hypothesis that "There is no significant difference between the maintenance priority preferences of tenants and the maintenance department" and reject the alternative hypothesis that "There are significant differences between the maintenance priority preferences of tenants and the maintenance department".

The fact that there is agreement among the tenants in their priority ranking of building defects, and there is no significant difference between the tenants and the maintenance departments in their priority preferences augurs well for the prioritisation of maintenance works in two ways. First, agreement between tenants on the one hand and the maintenance departments on the other ensures that the two sides do not have conflicting expectations. Secondly, agreement among tenants themselves makes it possible for maintenance management to fix priorities acceptable to the generality of the tenants.

\subsection{Maintenance Performance Rating and Tenants' Satisfaction}

As stated earlier, the level of tenants' satisfaction is an index of maintenance performance. For tenants' satisfaction to be used as a measure of housing maintenance performance, it is important that tenants be in agreement in their assessments of the various attributes of maintenance satisfaction. Also, for tenant ratings of their satisfaction to be objective it must be based on the actual state of maintenance of their dwellings and not on extraneous factors. To examine these issues, two null hypotheses were postulated as follows:

- There is no agreement among tenants in their satisfaction rating of housing maintenance management.

- There is no significant correlation between users' perception of the level of maintenance of a particular building and the prevalent level of user satisfaction. 


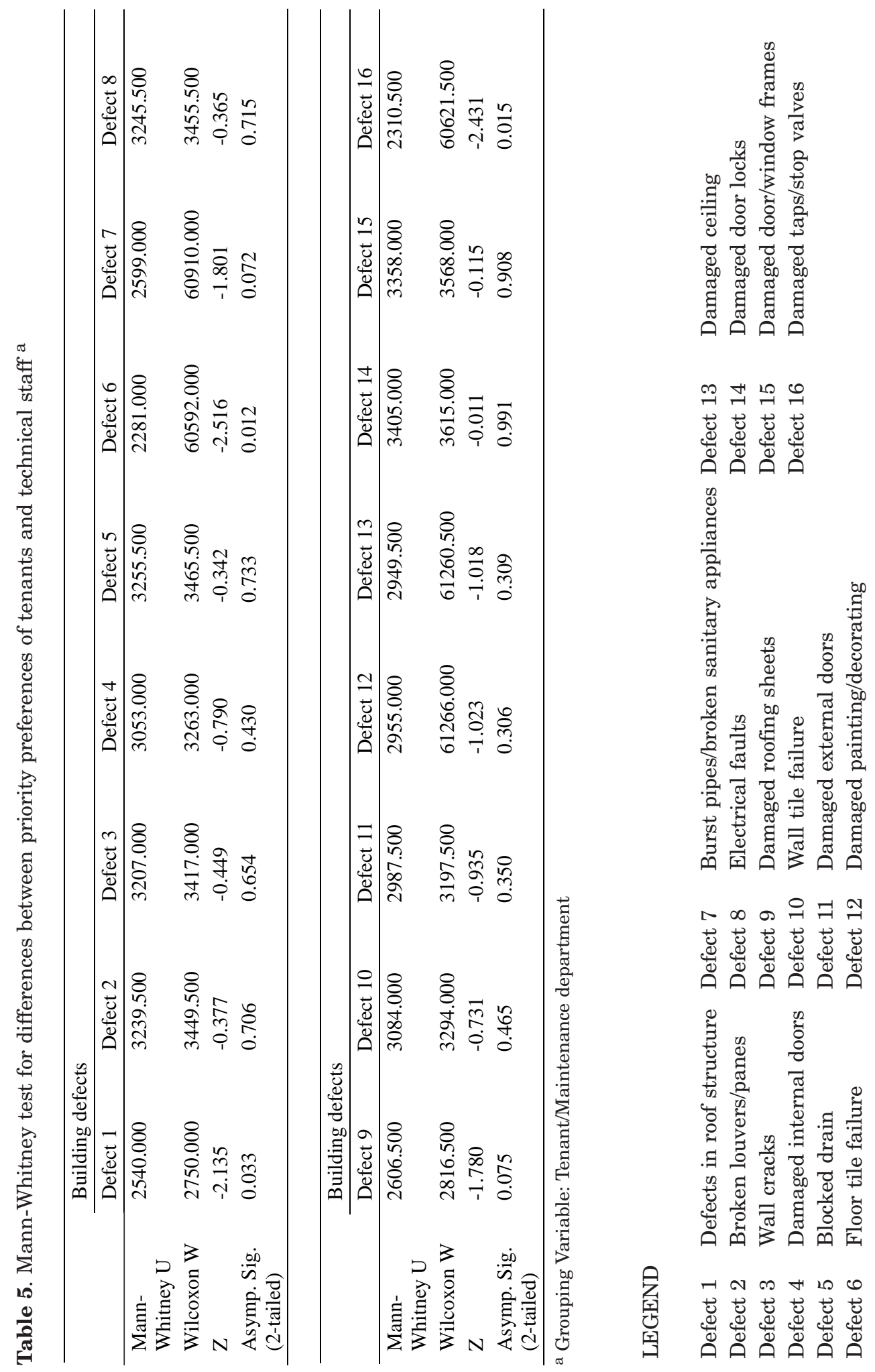


The first hypothesis is tested using Kendall's test of concordance (Table 6). For the significance level $\mathrm{p}<0.05$, we reject the null hypothesis that "There is no agreement among tenants in their satisfaction rating of housing maintenance management" and accept the alternative hypothesis that "there is agreement among tenants in their satisfaction rating of housing maintenance management".

With the results above we proceed in Table 7 to analyse tenants' satisfaction with the various attributes of the housing maintenance systems, using a scale from 1 = Very dissatisfied to 7 = Very satisfied. The results show that the quality of the environment and surroundings is the maintenance attribute most satisfactory to the tenants while the level of maintenance backlog is the least satisfactory. The high, unsatisfactory level of maintenance backlog stemmed from the fact that in the past five years the maintenance departments received just about $15 \%$ of their actual budgetary requirements from the institutions.

Table 6. Kendall's coefficient of concordance test for tenants' satisfaction with maintenance attributes

\begin{tabular}{lllll}
\hline No. of Cases & W & $\chi^{2}$ & df & Significance \\
\hline 330 & 0.208 & 755.894 & 11 & 0.000 \\
\hline
\end{tabular}

Table 7. Tenants' satisfaction rating of attributes of the maintenance system

\begin{tabular}{|c|c|c|c|c|c|c|c|c|c|}
\hline \multirow[t]{2}{*}{ Maintenance attribute } & \multicolumn{7}{|c|}{ SPSS Valid Percentage Scores } & \multirow{2}{*}{$\begin{array}{l}\text { Severity } \\
\text { index }(\%)\end{array}$} & \multirow[t]{2}{*}{ Rank } \\
\hline & 1 & 2 & 3 & 4 & 5 & 6 & 7 & & \\
\hline $\begin{array}{l}\text { Procedures for reporting defects and } \\
\text { getting work done }\end{array}$ & 14.2 & 22.2 & 8.8 & 31.3 & 10.9 & 11.1 & 1.6 & 48.93 & 6 \\
\hline $\begin{array}{l}\text { Maintenance departments' } \\
\text { complaints response time }\end{array}$ & 22.7 & 26.5 & 17.3 & 22.4 & 6.4 & 4.1 & 0.5 & 39.61 & 9 \\
\hline Behaviour of maintenance staff & 12.1 & 17.8 & 9.6 & 35.9 & 12.4 & 10.3 & 1.8 & 50.93 & 5 \\
\hline Level of maintenance backlog & 23.6 & 24.4 & 19.1 & 22.5 & 6.1 & 3.4 & 0.8 & 39.46 & 10 \\
\hline $\begin{array}{l}\text { Level of nuisance (i.e. disturbance } \\
\text { and interference with your privacy } \\
\text { by maintenance staff }\end{array}$ & 5.2 & 7.6 & 9.5 & 29.9 & 20.9 & 22.6 & 4.3 & 62.67 & 2 \\
\hline $\begin{array}{l}\text { Speed of work (i.e. time taken by } \\
\text { maintenance staff to do repairs in } \\
\text { your house) }\end{array}$ & 17.2 & 19.8 & 12.4 & 31.9 & 8.7 & 7.9 & 2.1 & 46.74 & 7 \\
\hline $\begin{array}{l}\text { Quality of repairs done by } \\
\text { maintenance staff in your house }\end{array}$ & 7.0 & 8.9 & 10.2 & 35.5 & 14.4 & 20.6 & 3.4 & 59.54 & 3 \\
\hline $\begin{array}{l}\text { Cost to tenant (i.e. money/time you } \\
\text { spend reporting faults, transporting } \\
\text { maintenance staff and buying some } \\
\text { materials, if any }\end{array}$ & 23.0 & 22.2 & 14.8 & 27.7 & 6.9 & 4.5 & 1.1 & 41.69 & 8 \\
\hline $\begin{array}{l}\text { Functionality of the house (i.e. your } \\
\text { enjoyment of the use of the house } \\
\text { and services like water, electricity, } \\
\text { etc.) }\end{array}$ & 8.8 & 12.9 & 7.3 & 32.3 & 16.7 & 17.7 & 4.3 & 57.93 & 4 \\
\hline Aesthetics of the house & 6.2 & 11.9 & 7.3 & 39.5 & 16.6 & 16.9 & 1.6 & 57.93 & 4 \\
\hline $\begin{array}{l}\text { The environment and surroundings } \\
\text { of your house }\end{array}$ & 5.8 & 6.3 & 6.1 & 30.2 & 19.5 & 24.1 & 7.9 & 64.99 & 1 \\
\hline
\end{tabular}


Table 8 shows that out of the 391 respondents, $129(33.1 \%)$ rated their satisfaction with the overall maintenance of their dwellings below average while $111(28.4 \%)$ rated it above average. Only 14 respondents $(3.6 \%)$ were "Very satisfied" while $37(9.5 \%)$ were "Very unsatisfied". The majority of 151 (38.6\%) were only averagely satisfied.

Applying the formula for severity index (explained in the methodology) to the results in Table 8, an overall tenant satisfaction index (TSI) of 0.55 is obtained, which on a scale of 0 to 1 is just average.

In Table 9, the overall rating (from $1=$ Very bad to $7=$ Very good) of the state of maintenance of the houses by the tenants is presented. Again, using the formula for severity index earlier given, a state of maintenance index (SMI) of 0.57 is calculated from the results in Table 9. The SMI is just above average on a scale of 0 to 1 .
The second null hypothesis that "There is no significant correlation between users' perception of the level of maintenance of a particular dwelling and the prevalent level of user satisfaction" is tested in Table 10 by running Pearson's correlation between the tenants' overall rating of the state of maintenance of their dwellings (from very bad to very good) and their satisfaction with the overall maintenance of their dwellings.

The analysis in Table 10 indicates a positive correlation between the two variables. For $\mathrm{p}<0.01$, the correlation is highly significant at the $1 \%$ level. Hence we reject the null hypothesis that "There is no significant correlation between users' perception of the level of maintenance of a particular dwelling and the prevalent level of user satisfaction" and accept the alternative hypothesis that "There is significant correlation between users' perception of the level of maintenance of a particular dwell-

Table 8. Tenants' satisfaction with the state of maintenance of their dwellings

\begin{tabular}{llll}
\hline Rating & Frequency & Valid percent & Cumulative percent \\
\hline 1. Very unsatisfied & 37 & 9.5 & 9.5 \\
2. Unsatisfied & 46 & 11.8 & 21.2 \\
3. Quite unsatisfied & 46 & 11.8 & 33.0 \\
4. Average & 151 & 38.6 & 71.6 \\
5. Quite satisfied & 48 & 12.3 & 83.9 \\
6. Satisfied & 49 & 12.5 & 96.4 \\
7. Very satisfied & 14 & 3.6 & 100.0 \\
\hline Total & 391 & 100.0 & \\
\hline
\end{tabular}

Table 9. Overall maintenance rating of the housing stock by tenants

\begin{tabular}{llll}
\hline Rating & Frequency & Valid percent & Cumulative percent \\
\hline 1. Very bad & 30 & 7.7 & 7.7 \\
2. Bad & 41 & 10.6 & 18.3 \\
3. Quite bad & 44 & 11.3 & 29.6 \\
4. Average & 150 & 38.7 & 68.3 \\
5. Quite good & 56 & 14.4 & 82.7 \\
6. Good & 52 & 13.4 & 96.1 \\
7. Very good & 15 & 3.9 & 100.0 \\
\hline Total & 388 & 100.0 & \\
\hline
\end{tabular}


Table 10. Correlation between user satisfaction and state of maintenance

\begin{tabular}{llll}
\hline & & $\begin{array}{l}\text { State of maintenance of the } \\
\text { houses }\end{array}$ & $\begin{array}{l}\text { Level of tenant satisfaction } \\
\text { with the maintenance of the } \\
\text { houses }\end{array}$ \\
\hline $\begin{array}{l}\text { State of maintenance of the } \\
\text { houses }\end{array}$ & Pearson Correlation & 1 & $0.532^{* *}$ \\
\cline { 2 - 4 } & Sig. (2-tailed) & $\cdot$ & 0.000 \\
\hline $\begin{array}{l}\text { Level of tenant satisfaction with } \\
\text { the maintenance of the houses }\end{array}$ & Pearson Correlation & $0.532^{* *}$ & 1 \\
\cline { 2 - 4 } & Sig. (2-tailed) & 0.000 &. \\
\hline
\end{tabular}

** Correlation is significant at the 0.01 level (2-tailed).

a Listwise $\mathrm{N}=379$

ing and the prevalent level of user satisfaction". This implies that the tenant satisfaction index of 0.55 obtained represents the true level of tenant satisfaction based on the actual state of maintenance of the dwellings and not on extraneous factors. The maintenance departments can therefore rely on the results as feedback from the tenants to guide their decisions to improve performance

\section{CONCLUSIONS}

This paper reports the results of a questionnaire survey of 406 tenants in 3 large institutional housing estates in Nigeria. The aim of the survey was to assess tenants' maintenance awareness and responsibility as well as their level of satisfaction with the maintenance of their houses. The findings show that most of the tenants had the correct understanding of the rationale for maintenance and a high sense of responsibility towards the maintenance of their houses. This level of awareness and responsibility may be because the tenants were highly educated people, possessing qualifications ranging from first degrees or diplomas to doctorates in various fields.

There was agreement among the tenants on the priority order of competing repair demands. Also, there was no significant difference in the priority preferences of the tenants and the maintenance departments. The tenants' satisfaction with state of maintenance of their houses was just average, with the quality of the environment/surroundings and the backlog of maintenance work rated as the most and the least satisfactory attributes of the maintenance systems respectively. The study showed that tenants' perceptions of and satisfaction with the state of maintenance of their houses was based on the actual conditions of their houses. This study should therefore serve as a good feedback to the maintenance departments and guide them in taking remedial measures to improve their performance and boost tenants' satisfaction.

\section{REFERENCES}

Amole, B. (1989) Residents' assessment of the university housing estate in Ile-Ife, Nigeria. Journal of Studies in Environmental Design in West Africa, 8, p. 19-32.

Berger, L., Greenstein, J., Hoffman, M. and Uzan, J. (1991) Practical application of models for pavement maintenance management. Journal of Transportation Engineering-ASCE, 117(9), p. 2065-2078.

Bitner, M. J., Faranda, W. T., Hubbert, A. R. and Zeithaml, V. A. (1997) Customer contributions and roles in service delivery. International Journal of Service Industry Management, 8(3), p. 193-205.

Coakes, S. J. and Steed, L. G. (2001) SPSS: analysis without anguish, John Wiley \& Sons, Milton, UK. 
De Vaus, D. A. (1996) Surveys in social research, UCL Press, London.

Djebarni, R. and Al-Abed, A. (2000) Satisfaction level with neighbourhoods in low-income public housing in Yemen. Property Management, 18(4), p. 230-242.

Elhag, T. M. S. and Boussabaine, A. H. (1999) Evaluation of construction cost and time attributes, in Proc. of the $15^{\text {th }}$ ARCOM Conference, Vol. 2, Liverpool John Moores University, pp. 473-480.

El-Haram, M. A. and Horner, M. W. (2002) Factors affecting housing maintenance cost. Journal of Quality in Maintenance Engineering, 8(2), p. 115-123.

Federal Republic of Nigeria (1991) National housing policy for Nigeria. Federal Ministry of Works and Housing, Lagos.

Foster, A. (2000) Putting your house in order: evaluating tenant satisfaction with improvements to social housing. Available at http://www.hmtreasury.gov.uk/media/092FE/239.pdf [Accessed on 15 May, 2004].

Idrus, A. B. and Newman, J. B. (2002) Construction related factors influencing the choice of concrete floor systems. Construction Management and Economics, 20, p. 13-19.

Kangwa, J. and Olubodun, F. (2003a) An investigation into home owner maintenance awareness, management and skill-knowledge enhancing attributes. Structural Survey, 21(2), p. 70-78.

Kangwa, J. and Olubodun, F. (2003b) A factor approach to analysis of home maintenance outcomes and attributes of management successes in the owner-occupied sector. Structural Survey, 21(4), p. 158-172.

Koebel, C. T. and Etuk, E. (1998) Improving management of assisted housing through tenant feedback. Paper delivered at the meeting of the International Sociological Association Research Committee 43, Housing and the Built Environment, July 26-July 31, Montreal, Canada. Available at http://www.arch.vt.edu/caus/research/vchr/pdfreports/isa_pap.pdf [Accessed on 12 May, 2004].

Lee, R. (1995) Building maintenance management, Blackwell Science Ltd., Oxford, UK,

Lu, M. (1999) Determinants of residential satisfaction: ordered logit vs. regression models. Growth and Change, 30(2), p. 264-287.

McGeorge, D. and Betts, M. (1990) Systems approach to building maintenance cost forecast- ing. In Quah, L. K. (ed.): Building Maintenance and Modernisation Worldwide, Singapore, 1, p. 192-199.

National Housing Federation (2001) FEEDBACK: The tenant satisfaction survey service for social landlords - Three Rivers District Council survey report. Available at http:// www.threerivers.gov.uk/_table/housing/ tenant_survey.pdf [Accessed on 12 April, 2004].

Ngo, M. (1990) Asset management-a methodology for establishing maintenance standards. In Ireland, V. and Runeson, G. (eds.) Building Economics and Construction Management, University of Sidney, 3, p. 149-153.

Oladapo, A. A. (2005) An evaluation of the maintenance management of the staff housing estates of selected first generation universities in Southwestern Nigeria. Unpublished PhD. Thesis, Dept. of Building, Obafemi Awolowo University, Ile-Ife, Nigeria.

Olubodun, F. O. (1996) An empirical approach to the evaluation of factors in local authority housing maintenance requirements in the city of Manchester. Unpublished PhD. Thesis, Dept. of Surveying, University of Salford, Salford, England.

Ozdemir, O. B. (2002) Reinvestment decisions and rehabilitation in housing. In Ural, O., Abrantes, V. and Tadeu, A. (eds.) Housing constructionan interdisciplinary task, Coimbra, Portugal, 3, p. 1927-1934.

Pullin, L. and Haidar, A. (2003) Managerial values in local government-Victoria, Australia. The International Journal of Public Sector Management, 16(4), p. 286-302.

Ramamurthy, K. N. (1990) Management of maintenance and rehabilitation works. In Ireland, V. and Runeson, G. (eds.) Building Economics and Construction Management, University of Sydney, 3, p. 158-164.

Richardson, B. A. (1991) Defects and deterioration in buildings, Spon, London.

Rosenbaum, J. E., Stroh, L. K. and Flynn, C. A. (1998) Lake Parc Place: A study of mixed-income housing. Housing Policy Debate, 9(4), p. 703-740.

Satsangi, M. and Kearns, A. (1992) The use and interpretation of tenant satisfaction surveys in British social housing. Environment and Planning C-Government and Policy, 10, p. 317-331.

Seeley, I. H. (1987) Building maintenance, 
Macmillan Press Ltd., London.

Shen, Q., Lo, K. and Wang, Q. (1998) Priority setting in maintenance management: a modified multi-attribute approach using analytic hierarchy process. Construction Management and Economics, 16, p. 693-702.

So, A. T. P. and Leung, A. Y. T. (2004) Survey of attitudes towards buildings in three Chinese cities: Hong Kong, Shanghai and Taipei. Facilities, 22(3/4), p. 100-108.

Sungur, C. A. and Cagdas, G. (2003) Effects of housing morphology on user satisfaction. In Proceedings of $4^{\text {th }}$ International Space Syntax Symposium, London. Available at http:// www.spacesyntax.net/symposia/SSS4/ $\mathrm{s} \mathrm{h}$ o r t p a p e r - a b s t r a t s/ 114_Sungur_Abstract_.pdf [Accessed on 11 April, 2004].

Ukoha, O. M. and Beamish, J. O. (1997) Assessment of residents' satisfaction with public housing in Abuja, Nigeria. Habitat International, 21(4), p. 445-460.

van Wyk, K. and van Wyk, R. (2001) The management of housing processes. Paper presented at the 2001 IHSA Conference, Pietersburg, 10 October. Available at http://www.housing.gov.za/ Content/presentations/papers/docs_papers.pdf [Accessed on 11 April, 2004].

Varady, D. P. and Carrozza, M. A. (2000) Toward a better way to measure customer satisfaction levels in public housing: a report from Cincinnati. Housing Studies, 15(6), p. 797-825.

Vijverberg, G. (2000) Basing maintenance needs on accommodation policy. Building Research and Information, 28(1), p. 18-30.

Walker, D. H. T. (1994) An Investigation into Factors that Determine Building Construction time Performance. Unpublished PhD. Thesis, Department of Building and Construction Economics, Royal Melbourne Institute of Technology, Melbourne, Australia.

Walters, M. (1999) Performance measurement systems: a case study of customer satisfaction. Facilities, 17(3/4), p. 97-104.

Yip, N. M. (2001) Tenant participation and the management of public housing. The Estate Management Advisory Committee of Hong Kong. Property Management, 19(1), p. 10-18.

\section{SANTRAUKA}

\section{KA NIGERIJOS GYVENTOJAI ŽINO APIE INSTITUCIJŲ BŪSTŲ PRIEŽIŪRĄ, KOKS JŲ ATSAKOMYBĖS LYGIS IR KAIP JUOS TENKINA ŠIE BŪSTAI}

\section{Adebayo A. OLADAPO}

Nigerijoje būsto problema yra ir kiekybinè, ir kokybinè. Kokybinis aspektas, susijęs su turimu išteklių priežiūra, tapo svarbesnis kilus poreikiui išsaugoti ir sutvarkyti turimus išteklius, kad jie atitiktų priimtinus gyvenimo standartus. Institucijų būstų gyventojų yra gana daug, jie tiesiogiai patiria nesuremontuotų būstų nepatogumų. Taigi jie suinteresuoti prisidèti prie namų priežiūros optimizavimo, nors tam naudojami labai riboti priežiūros departamentų ištekliai Siekiant ivvertinti, ka iš tiesu gyventojai žino apie priežiūrą ir koks jų atsakomybès lygis, bei kiekybiškai išanalizuoti jų pasitenkinimą namų priežiūros būkle, buvo atliktas tyrimas. Rezultatai parodé, kad gyventojai yra labai atsakingi ir daug žino apie būsto priežiūrą, bet jų pasitenkinimas namų priežiūra tẻra vidutinis. 